\title{
Stent-in-stent technique for removal of the tracheal stent in patients with severe granulation tissue hyperplasia
}

\author{
Peng-Fei Xie ${ }^{1}$, Ying $\mathrm{Liu}^{2}$, Yu Qi ${ }^{3}$, Xiang-Nan $\mathrm{Li}^{3}$, Mei-Pan Yin ${ }^{1}$, Yue Zhao ${ }^{1}$, Chun-Xia $\mathrm{Li}^{1}$, Zhen $\mathrm{Li}^{1}$, \\ Gang $W_{u^{1}}$ \\ ${ }^{1}$ Department of Interventional Radiology, The First Affiliated Hospital of Zhengzhou University, Zhengzhou, China; ${ }^{2}$ Department of Respiratory, \\ The First Affiliated Hospital of Zhengzhou University, Zhengzhou, China; ${ }^{3}$ Departments of Thoracic Surgery and Oncology, The First Affiliated \\ Hospital of Zhengzhou University, Zhengzhou, China
}

Correspondence to: Gang Wu. Department of Interventional Radiology, The First Affiliated Hospital of Zhengzhou University, Zhengzhou 450052, China. Email: wuganghenan2004@zzu.edu.cn.

Submitted May 31, 2020. Accepted for publication Jun 11, 2021.

doi: 10.21037/qims-20-719

View this article at: https://dx.doi.org/10.21037/qims-20-719

\section{Introduction}

A tracheal stent implantation is an effective treatment for benign or malignant tracheal stenosis and tracheal fistula (1-6). Currently, covered self-expanding metal stents (SEMS) are generally used in benign cases and uncovered SEMS for treating malignant tracheal stenosis. However, the radial force of the stent on the trachea and the friction between the stent and the tracheal wall during coughing often provoke granulation tissue hyperplasia $(7,8)$. This hyperplasia, which appears at the ends of covered stents or over the entire stented area in the case of uncovered stents, results in incarceration of the stent and tracheal restenosis $(9,10)$. Removal of the stent is then necessary $(11,12)$.

Tracheal stent removal can result in complications such as a tracheal mucosal tear, tracheal perforation, mediastinal abscess, massive hemorrhage, and asphyxia (13-15). When the SEMS is embedded in hyperplastic granulation tissue, tracheal perforation and hemorrhage risks are especially high (16-18). Despite advances in interventional techniques and bronchoscopy, both stent removal and treatment of related complications remain difficult.

Inspired by the success of the stent-in-stent (SIS) technique for esophageal stent removal $(19,20)$, we applied it to the removal of tracheal SEMS in four patients with severe proliferative stenosis. We describe our technique and report the outcomes.

\section{Materials and methods}

A total of four patients with severe tracheal hyperplasia and embedded SEMS were treated using the SIS technique between June 2016 and April 2019. Patients were considered for this technique if they had a severely embedded stent according to the definition used for a tracheal embedded stent (20): $\geq 25 \%$ of the SEMS uncovered area buried in proliferative mucosa or malignant tissue overgrowth. The conventional removal method is considered highly risky in such cases.

The clinical data of the patients, including medical history, chest computed tomography (CT) and fiberoptic bronchoscopy findings, stent type and size, and complications were extracted from the case records and retrospectively analyzed. All procedures involving human participants were performed following the ethical standards of the institutional research committee and with the Helsinki Declaration (as revised in 2013). The patients gave written informed consent.

\section{Interventional technique}

\section{Preoperative care}

Preoperatively, the extent and location of hyperplastic granulation tissue were accurately determined by chest CT (Figure 1A,B) and fiberoptic bronchoscopy (Figure 1C,D). 

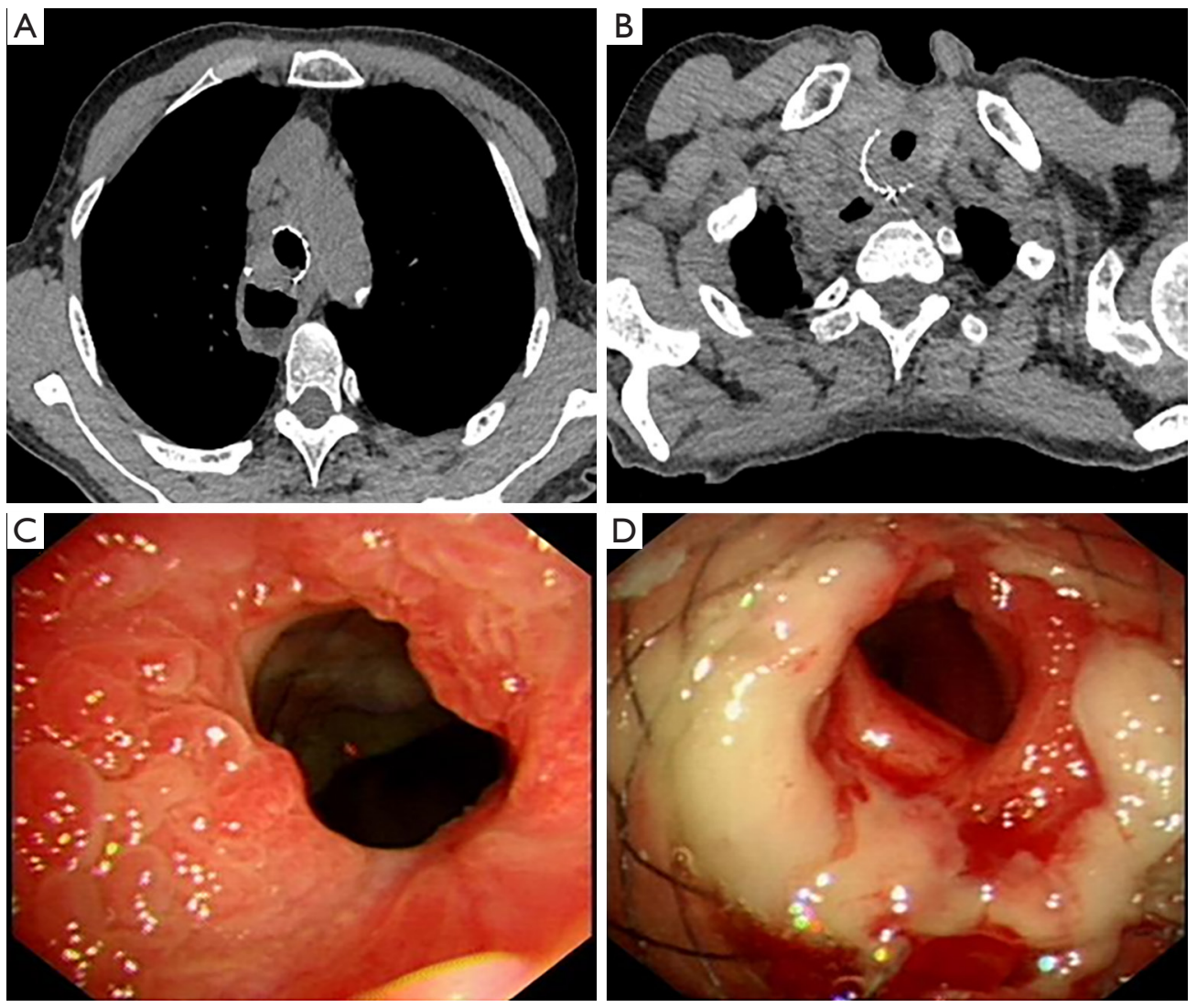

Figure 1 Chest computed tomography of Patient 1 shows stenoses at the proximal and the distal ends of the stent (A, B). Fiberoptic bronchoscopy also shows severe stenoses at the proximal and distal ends of stent (C, D).

The procedure was performed in awake sedated patients, with intramuscular injection of diazepam and anisodamine administered $30 \mathrm{~min}$ before the procedure, and $2-3 \mathrm{~mL}$ of $1 \%$ tetracaine hydrochloride sprayed orally just before the procedure.

\section{Implantation of a second tracheal stent}

The procedure was performed under fluoroscopic guidance. The patient was positioned supine on the examination table, and a mouth gag was inserted. A 0.035 -inch hydrophilic membrane guide wire and a $5 \mathrm{~F}$ vertebral artery catheter were introduced through the mouth and advanced past the stenosed stented area via the pharynx and trachea to a lower lobe bronchus. The guide wire was withdrawn, and $5 \mathrm{~mL}$ of $2 \%$ lidocaine was injected through the catheter to anesthetize the tracheal mucosa. A solution of $1 \mathrm{mg}$ epinephrine in $4 \mathrm{~mL}$ normal saline was then injected through the catheter to prevent tracheal mucosal bleeding.
The hydrophilic membrane guide wire was exchanged for a stiff guide wire, and the catheter was withdrawn. A covered tracheal SEMS stent and delivery system (Micro-Tech Co., Ltd., Nanjing, China) were inserted along the stiff guide wire. With the same diameter as the original stent but longer by $1-2 \mathrm{~cm}$, the stent was quickly released at the position of the original stent. The conveyor was removed, and the position and expansion of the stent were observed by fluoroscopy. The patient's vital signs were checked.

\section{Double tracheal stent removal}

Both tracheal stents were removed 10-14 days later. As before, thoracic CT and fiberoptic bronchoscopy were performed before the procedure to observe the position of the stents and the decrease in granulation tissue. Then, as described for stent placement, a stiff guide wire was inserted into a lower lobe bronchus. A $12 \mathrm{~F}$ long sheath was introduced along the guide wire into the lumen of the 


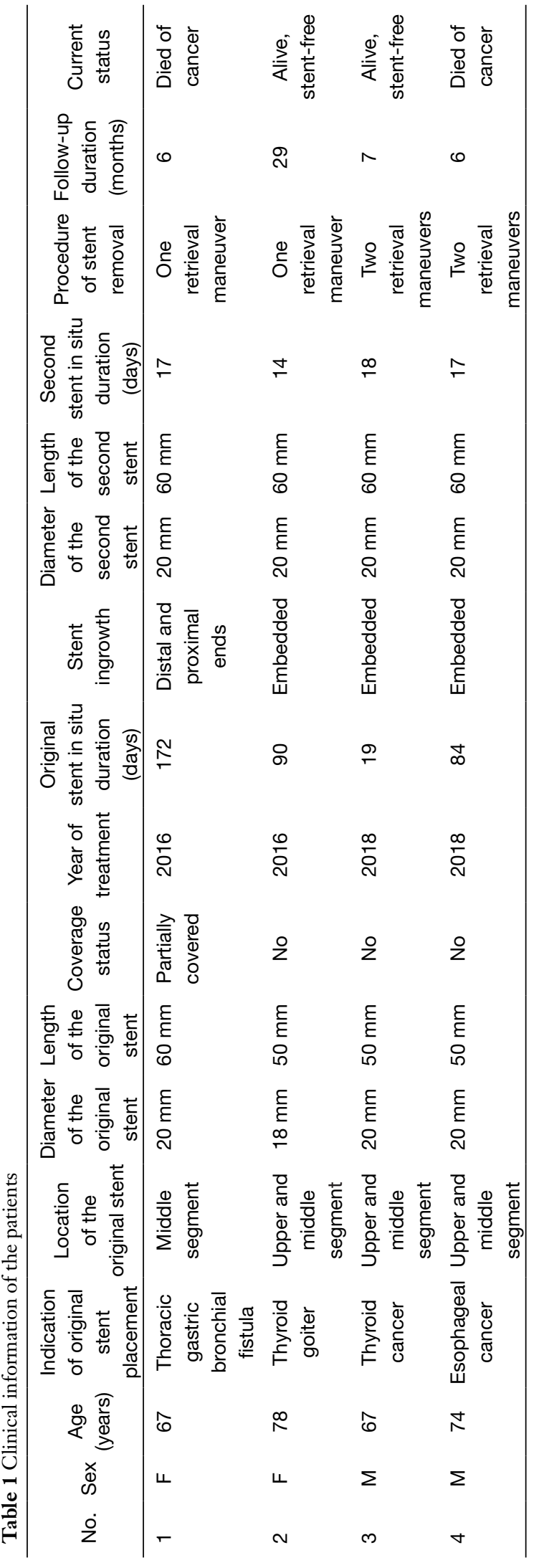

stent. The stent removal hook (Micro-Tech Co., Ltd.) was advanced through the sheath till it extended approximately $2 \mathrm{~cm}$ beyond the end of the sheath. The metal wire at the lower end of the second stent was hooked, and, with the guide wire fixed firmly, steady traction was exerted so that the stent invaginated into the sheath, which was then pulled out. The original stent was then removed in the same way (Video 1). The patient's vital signs and blood loss were closely monitored throughout the procedure.

\section{Results}

The four patients (two males, two females) had a median age of 71.5 years (range, $67-78$ years); Table 1 summarizes their characteristics. The median indwelling time of the first stent was 91.3 days (range, 19-172 days). Patients 2, 3, and 4 had received emergency uncovered tracheal stent placements because they had initially presented with severe tracheal stenosis. All patients developed tracheal restenosis due to granulation tissue hyperplasia and presented with dyspnea or retained sputum. At admission, thoracic CT and fiberoptic bronchoscopy showed severe granulation tissue hyperplasia at both ends of the stents, with hyperplasia also present within the stent in the two patients who had received uncovered stents. The trachea was severely stenotic in all patients.

When Patient 1 was treated, a sufficiently long covered tracheal stent (i.e., $70 \mathrm{~mm}$ ) was not available, so two shorter covered stents were used. One stent was first placed such that it extended $20 \mathrm{~mm}$ below the lower end of the first stent. One week later, when the stenosis had been relieved, the second stent was removed, and another was inserted such that it extended $20 \mathrm{~mm}$ above the upper end of the first stent (Figure 2).

In all patients, the second covered SEMS was successfully placed on the first attempt. The second stents were left in place for a median of 16.5 days (range 14-18 days). No stent migration occurred. For Patients 1 and 2, both stents were hooked and pulled out together (Figure 3). For Patients 3 and 4, the two stents were removed separately: the second stent followed by the first stent. Stents removal was successful in all patients; there were no serious complications such as major hemorrhage, tracheal rupture, or mediastinal emphysema. All patients had relief of dyspnea after stent removal.

Patient 1 had no recurrence of fistula or dyspnea but died of end-stage malignant disease 6 months after the procedure. Patients 2 and 3 survived without recurrence of dyspnea. Patient 4 had tumor recurrence and developed 

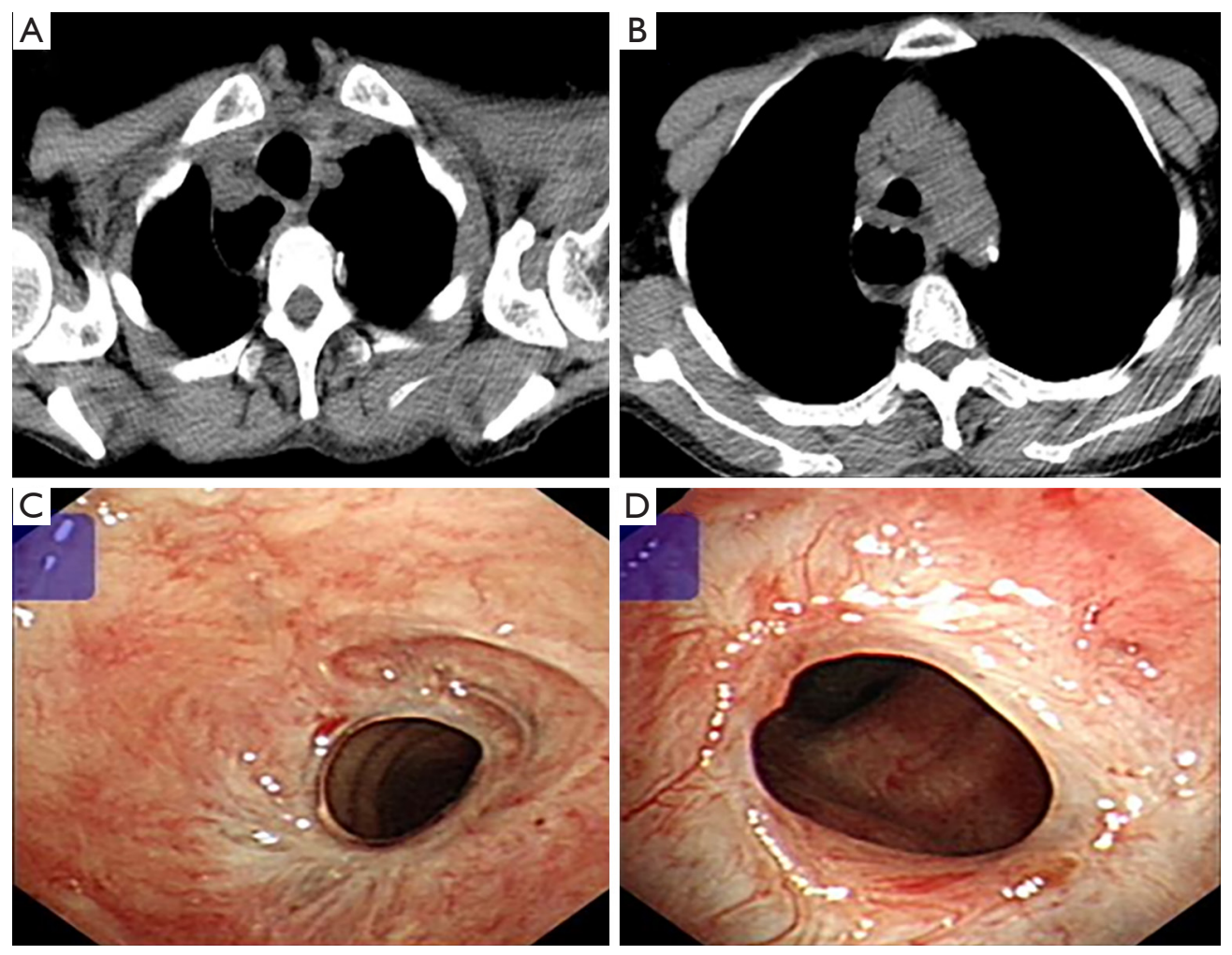

Figure 2 Disappearance of the stenoses after stent removal (A, B) and no stenoses visible after stent removal (C, D).

tracheal restenosis 2 months after stent removal, requiring placement of a new tracheal stent, but has survived without recurrence of dyspnea.

\section{Discussion}

Stent implantation has been traditionally used to treat tracheal stenosis due to sarcoidosis, tuberculosis, tumor invasion or compression, and iatrogenic causes $(14,16,21,22)$. With the introduction of covered SEMS, the indications for tracheal stent implantation now include bronchopleural fistula and gastrotracheal fistula $(3,4,6,23)$. SEMS are easier to place than silicone stents and cause less damage to the trachea. However, granulation tissue proliferation occurs more often with SEMS than with silicone stents. Compared with silicone stents, SEMS may be used in select cases of benign disease. The deployment mechanism of SEMS may be better suited for use in severe benign airway stenosis and in patients who cannot undergo rigid bronchoscopy (24).

The probability of complications such as restenosis, granulation hyperplasia, and stent fracture increases with stent indwelling time (8-10). Complications increase hospitalization costs and may even fail stent removal $(7,25)$. Tracheal restenosis is common after stenting, regardless of the type of stent used (7-10), and may be due to progressive malignant tumor growth or proliferation of granulation tissue at the site of stent implantation (26). Laser electrocoagulation, argon plasma coagulation, balloon dilation, and bronchoscopic cryoablation are some of the options available for relieving restenosis (16). Stent removal or re-implantation of the stent can also be effective $(11,12)$. Bronchoscopic stent removal is widely used (27-32), but only a few reports of stent removal use an interventional technique under fluoroscopic guidance and local anesthesia (33).

The advantage of stent removal using rigid bronchoscopy is that the trachea above the stent can be directly observed. After the stent is taken out, ablation of granulation tissue and hemostatic therapy can be performed under direct vision. A major disadvantage is that the bronchoscope cannot be inserted past the stent for cautery if there is severe hyperplasia. Furthermore, bronchoscopic stent removal requires general anesthesia, and there is a high risk of massive hemorrhage and mediastinal fistula.

The SIS technique of stent removal is useful when the stent 

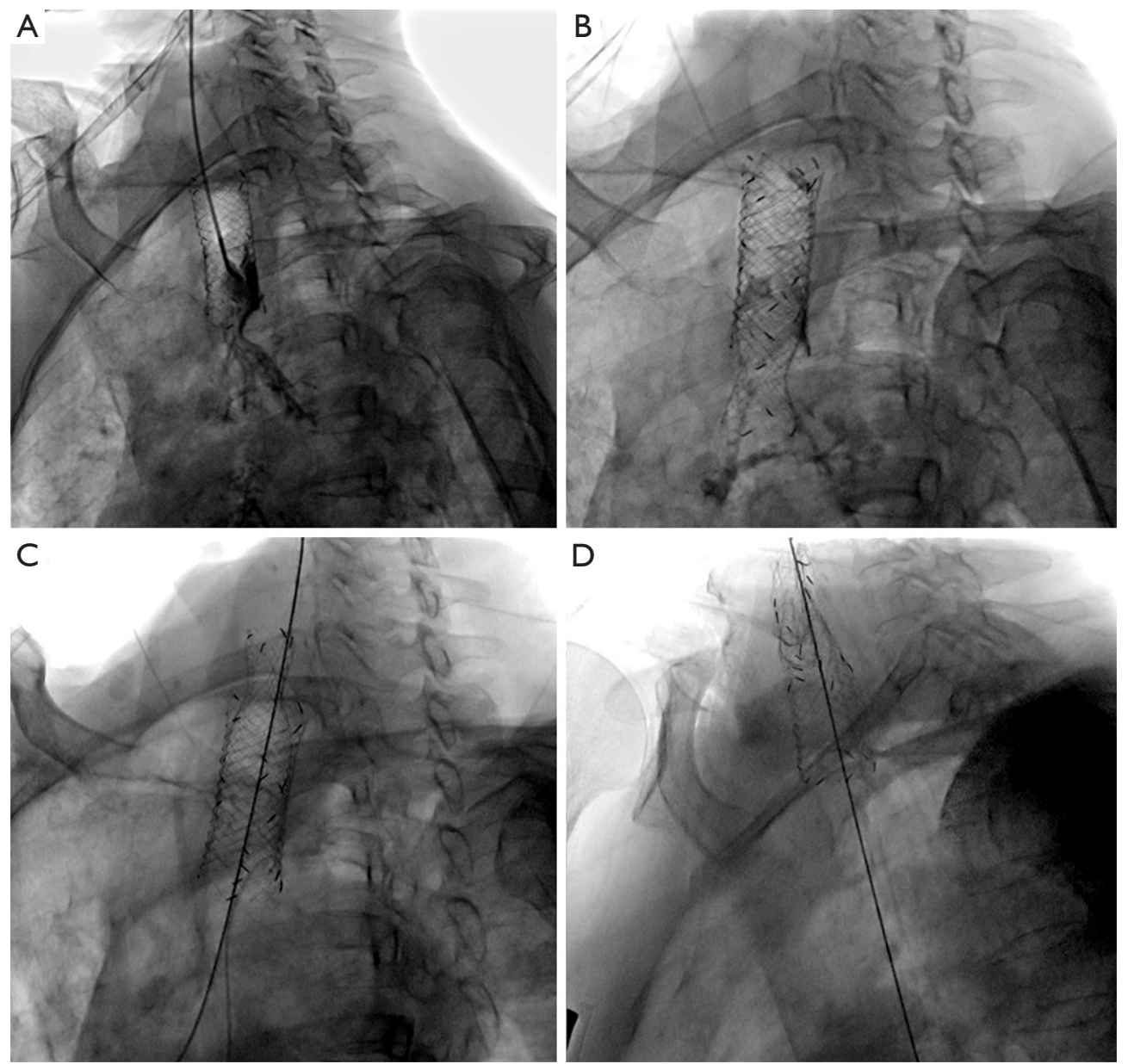

Figure 3 Stent-in-stent technique. A stenosis is present at the distal end of stent (A); a covered stent is placed (B); the second stent is removed (C); and finally, the first stent is removed (D).

is embedded in the mucosa or incarcerated in hyperplastic granulation tissue. A large-diameter stent placed within the original stent promotes bronchial mucosal necrosis and makes stent removal easier. The SIS technique has been successfully applied under endoscopy in gastroenterological diseases, especially in the treatment of biliary stricture (34). There are a few reports of the application of the SIS technique in the trachea. Watanabe et al. successfully used the SIS technique in a patient with malignant tracheal restenosis (35). $\mathrm{Xu}$ et al. used the Gianturco- $Z$ stent with the SIS technique to relieve tracheobronchial strictures (mostly malignant strictures) and achieved a good improvement in quality of life in patients with late-stage carcinoma (36). Bondue et al. successfully used the SIS technique to relieve proximal bronchial restenosis in two patients: one patient with malignant stricture and the other with bronchial stenosis after lung transplantation (37).
For esophageal stent removal by the SIS technique, the second stent can be left in place for up to 212 days (20). In the present patients, the second covered stent was inserted and left in place for a period ranging from 14 to 18 days, which is similar to the duration reported by DaVee et al. in their report of using the SIS technique for removal of esophageal stents (20). We believe this is the optimum indwelling time. There is a higher risk of stent migration and restenosis with a longer duration, and, with a shorter duration, there is insufficient necrosis of the granulation tissue and, therefore, a higher risk of injury during removal of the first stent.

The main limitation of this study is that it is a retrospective review of only four patients. Our conclusion regarding the efficacy and safety of the technique, and the optimum indwelling time for the second stent, need to be validated in larger samples. 


\section{Conclusions}

The SIS technique under fluoroscopy appears to be a feasible and safe method for removing embedded tracheal metal stents. Our findings need to be confirmed in larger cohorts.

\section{Acknowledgments}

Funding: This study was supported by the National Natural Science Foundation of China (Grant No. 81871466).

\section{Footnote}

Conflicts of Interest: All authors have completed the ICMJE uniform disclosure form (available at https://dx.doi. org/10.21037/qims-20-719). The authors have no conflicts of interest to declare.

Ethical Statement: The authors are accountable for all aspects of the work in ensuring that questions related to the accuracy or integrity of any part of the work are appropriately investigated and resolved. All procedures performed in studies involving human participants were following the ethical standards of the institutional research committee and with the Helsinki Declaration (as revised in 2013). The patients gave written informed consent.

Open Access Statement: This is an Open Access article distributed in accordance with the Creative Commons Attribution-NonCommercial-NoDerivs 4.0 International License (CC BY-NC-ND 4.0), which permits the noncommercial replication and distribution of the article with the strict proviso that no changes or edits are made and the original work is properly cited (including links to both the formal publication through the relevant DOI and the license). See: https://creativecommons.org/licenses/by-nc-nd/4.0/.

\section{References}

1. Han X, Al-Tariq Q, Zhao Y, Li L, Cheng Z, Wang H, Liu C, Jiao D, Wu G. Customized Hinged Covered Metallic Stentsfor the Treatment of Benign Main Bronchial Stenosis. Ann Thorac Surg 2017;104:420-5.

2. Han X, Li L, Zhao Y, Liu C, Jiao D, Ren K, Wu G. Individualized airway-covered stent implantation therapy for thoracogastric airway fistula after esophagectomy. Surg Endosc 2017;31:1713-8.
3. Han X, Wu G, Li Y, Li M. A Novel Approach: Treatment of Bronchial Stump Fistula With a Plugged, BulletShaped, Angled Stent. Ann Thorac Surg 2006;81:1867-71.

4. Han XW, Wu G, Li YD, Zhang QX, Guan S, Ma N, Ma J. Overcoming the Delivery Limitation: Results of an Approach to Implanting an Integrated Self-expanding Y-shaped Metallic Stent in the Carina. J Vasc Interv Radiol 2008;19:742-7.

5. Ma J, Han X, Wu G, Jiao D, Ren K, Bi Y. Outcomes of Temporary Partially Covered Stent Placement for Benign Tracheobronchial Stenosis. Cardiovasc Intervent Radiol 2016;39:1144-51.

6. Wu G, Li ZM, Han XW, Wang ZG, Lu HB, Zhu M, Ren KW. Right bronchopleural fistula treated with a novel, Y-shaped, single-plugged, covered, metallic airway stent. Acta Radiol 2013;54:656-60.

7. Noppen M, Stratakos G, D'Haese J, Meysman M, Vinken W. Removal of Covered Self-Expandable Metallic Airway Stents in Benign Disorders. Chest 2005;127:482-7.

8. Chung FT, Lin SM, Chen HC, Chou CL, Yu CT, Liu CY, Wang CH, Lin HC, Huang CD, Kuo HP. Factors leading to tracheobronchial self-expandable metallic stent fracture. J Thorac Cardiovasc Surg 2008;136:1328-35.

9. Chung FT, Lin SM, Chou CL, Chen HC, Liu CY, Yu CT, Kuo HP. Factors Leading to Obstructive Granulation Tissue Formation after Ultraflex Stenting in Benign Tracheal Narrowing. Thorac Cardiovasc Surg 2010;58:102-7.

10. Chung FT, Chen HC, Chou CL, Yu CT, Kuo CH, Kuo HP, Lin SM. An outcome analysis of self-expandable metallic stents in central airway obstruction: a cohort study. J Cardiothorac Surg 2011;6:46.

11. Fruchter O, Raviv Y, Fox BD, Kramer MR. Removal of metallic tracheobronchial stents in lung transplantation with flexible bronchoscopy. J Cardiothorac Surg 2010;5:72.

12. Tanigawa N, Kariya S, Komemushi A, Nakatani M, Yagi R, Sawada S. Metallic stent placement for malignant airway stenosis. Minim Invasive Ther Allied Technol 2012;21:108-12.

13. Lunn W, Feller-Kopman D, Wahidi M, Ashiku S, Thurer R, Ernst A. Endoscopic removal of metallic airway stents. Chest 2005;127:2106-12.

14. Gottlieb J, Fuehner T, Dierich M, Wiesner O, Simon AR, Welte T. Are metallic stents really safe? A longterm analysis in lung transplant recipients. Eur Respir J 2009;34:1417-22.

15. Murthy SC, Gildea TR, Mehta AC. Removal of selfexpandable metallic stents: is it possible? Semin Respir Crit Care Med 2004;25:381-5. 
16. Ernst A, Feller-Kopman D, Becker HD, Mehta AC. Central airway obstruction. Am J Respir Crit Care Med 2004;169:1278-97.

17. Tringali A, Blero D, Boškoski I, Familiari P, Perri V, Devière J, Costamagna G. Difficult removal of fully covered self expandable metal stents (SEMS) for benign biliary strictures: the "SEMS in SEMS" technique. Dig Liver Dis 2014;46:568-71.

18. Khemasuwan D, Gildea TR, Machuzak MS. Complex metallic stent removal: decade after deployment. J Bronchology Interv Pulmonol 2014;21:358-60.

19. Aiolfi A, Bona D, Ceriani C, Porro M, Bonavina L. Stent-in-stent, a safe and effective technique to remove fully embedded esophageal metal stents: case series and literature review. Endosc Int Open 2015;3:E296-9.

20. DaVee T, Irani S, Leggett CL, Berzosa Corella M, Grooteman KV, Wong Kee Song LM, Wallace MB, Kozarek RA, Baron TH.. Stent-in-stent technique for removal of embedded partially covered self-expanding metal stents. Surg Endosc 2016;30:2332-41.

21. Dutau H, Reynaud-Gaubert M, Thomas PA. Endoscopic management of post-lung transplantation anastomotic stenosis: metallic, silicone or biodegradable stents. Eur J Cardiothorac Surg 2012;41:1216-7.

22. Serrano C, Laborda A, Lozano JM, Caballero H, Sebastián A, Lopera J, de Gregorio MÁ. Metallic stents for tracheobronchial pathology treatment. Cardiovasc Intervent Radiol 2013;36:1614-23.

23. Li TF, Duan XH, Han XW, Wu G, Ren JZ, Ren KW, Lu HB. Application of combined-type Y-shaped covered metallic stents for the treatment of gastrotracheal fistulas and gastrobronchial fistulas. J Thorac Cardiovasc Surg 2016;152:557-563.

24. Dutau H, Cavailles A, Sakr L, Badier M, Gaubert JY, Boniface S, Doddoli C, Thomas P, Reynaud-Gaubert M. A retrospective study of silicone stent placement for management of anastomotic airway complications in lung transplant recipients: short- and long-term outcomes. J Heart Lung Transplant 2010;29:658-64.

25. Chung FT, Chen GY, Chou CL, Chen HC, Yu CT, Kuo $\mathrm{CH}$, Lin SM, Kuo HP. Remove airway ultraflex stents by flexible bronchoscope. Am J Med Sci 2012;343:267-72.

26. Freitag L, Ernst A, Unger M, Kovitz K, Marquette CH. A proposed classification system of central airway stenosis. Eur Respir J 2007;30:7-12.

27. Gaissert HA, Grillo HC, Wright CD, Donahue DM, Wain JC, Mathisen DJ. Complication of benign tracheobronchial strictures by self-expanding metal stents.
J Thorac Cardiovasc Surg 2003;126:744-7.

28. Miyazawa T, Yamakido M, Ikeda S, Furukawa K, Takiguchi Y, Tada H, Shirakusa T. Implantation of ultraflex nitinol stents in malignant tracheobronchial stenoses. Chest 2000;118:959-65.

29. Filler RM, Forte V, Chait P. Tracheobronchial stenting for the treatment of airway obstruction. J Pediatr Surg 1998;33:304-11.

30. Rousseau H, Dahan M, Lauque D, Carré P, Didier A, Bilbao I, Herrero J, Blancjouvant F, Joffre F. Selfexpandable prostheses in the tracheobronchial tree. Radiology 1993;188:199-203.

31. Nashef SA, Dromer C, Velly JF, Labrousse L, Couraud L. Expanding wire stents in benign tracheobronchial disease: indications and complications. Ann Thorac Surg 1992;54:937-40.

32. Zakaluzny SA, Lane JD, Mair EA. Complications of tracheobronchial airway stents. Otolaryngol Head Neck Surg 2003;128:478-88.

33. Bi Y, Chen H, Li J, Fu P, Ren J, Han X, Wu G. Fluoroscopyguided removal of individualised airway-covered stents for airway fistulas. Clin Radiol 2018;73:832.e1-e8.

34. Kato H, Tsutsumi K, Kawamoto H, Okada H. Current status of endoscopic biliary drainage for unresectable malignant hilar biliary strictures. World J Gastrointest Endosc 2015;7:1032-8.

35. Watanabe H, Uruma T, Tsunoda T, Machida Y, Nagasaki S, Kobayashi K, Yamamoto M, Sekine H, Igarashi H, Ishii H, Tazaki G, Kondo T. Palliation of malignant tracheal stenosis with a second implantation of an expandable metallic stent under endotracheal intubation. Tokai J Exp Clin Med 2013;38:46-51.

36. Xu X, Tajima H, Ishioh M, Watari J, Miyashita T, Kumazaki T, Ogawa R. Study on the treatment of tracheobronchial stenosis using expandable metallic stents. J Nippon Med Sch 2001;68:318-27.

37. Bondue B, Schlossmacher P, Knoop C, Etienne I, Luce S, Sokolow Y, Leduc D. Stent-in-Stent Technique for the Treatment of Proximal Bronchial Restenosis after Insertion of Metallic Stents: A Report of Two Cases. Case Rep Pulmonol 2016;2016:6742349.

Cite this article as: Xie PF, Liu Y, Qi Y, Li XN, Yin MP, Zhao Y, Li CX, Li Z, Wu G. Stent-in-stent technique for removal of the tracheal stent in patients with severe granulation tissue hyperplasia. Quant Imaging Med Surg 2021;11(11):46764682. doi: 10.21037/qims-20-719 